\title{
Land Tenure of the Malay People in North Sumatera: From Normative Trap to the Historical Denial
}

\author{
Edy Ikhsan \\ Faculty of Law, University of Sumatera Utara \\ Jln. Dr. T. Mansur No. 9, Kampus Padang Bulan, Medan 20155, North Sumatera, Indonesia \\ Tel./Fax: +62-61-8213571 E-mail: eikhsan@yahoo.com
}

Submitted: Sep 7, 2016; Reviewed: Nov 29, 2016; Accepted: Dec 12, 2016

\begin{abstract}
The following brief analysis is trying to look at the shifting mechanism of land rights of the Malay people from a historical perspective. The point of analysis stems from the description contained in the literature of customary laws produced by some academics and of the Dutch colonial officials. It subsequently runs using of some secondary materials and other colonial-based archives. The analysis finally concludes that in the span of nearly a half of a century, since the period of the Dutch, Japanese capitulation, the period of independence, the land rights of the Malay people has become a "toy play" of the ruling regimes, with all formulas being implemented in each period. The laws imposed upon this well-known fertile land have been successfully enriching the rulers and a wide range of business people with strong access to it.
\end{abstract}

Keywords: Communal Land Rights; Indigenous People; Land Tenure; Malay People; North Sumatera

DOI: 10.20956/halrev.v2i3.316

\section{INTRODUCTION}

About 150 years after Dutch planters arrived in North Sumatra, Indonesia, land rights ownership previously held by the people with their communal leaders (chieftains of Kampong and Kedatukan) had shifted rapidly. Foreign planters were among the first to acquire and hold the rights until 1942; before Indonesia's independence. Japan later took over the rights for a relatively short time (3 years) until 1945. Upon nationalization of Dutch companies in Indonesia (1958), the land ownership was taken over by Indonesian government. Changes in Indonesia's state administration, from pre-independence autonomous kingdoms to a unitary state finally nullified authorities and resources held for hundred of years.

This article aims at unraveling the influence of political and legal policies taken by the Dutch colonialists and the Indonesian government causing Malay Muslims in North Sumatra lose their communal lands, by reviewing available primary and secondary sources. The first part of this paper will explain positions of the people, Kedatukan ${ }^{l}$

Kedatukan is an autonom chieftainship leads by a reputable person called Datuk. The Datuks controls the laws in his region and especially land's distribution. 
and Sultan (The King) in relation to ownership and distribution of lands, particularly the communal lands. This paper will then explain the normative entrapment applied on the communal land, through land concession contracts agreed between Sultans and foreign planters and finally through nationalization of Dutch companies in Indonesia.

This paper is concluded with explanations of how the state conduct criminalization against Malay people who try to reclaim their communal lands by criticizing laws passed to secure state's interest on resources and profits produced by the land.

\section{ANALYSIS AND DISCUSSION}

\section{Land Ownership Before the Colonial Era}

The facts that almost all historical records and documentations on customary laws ever existed to have shown the position of the people and their leaders at the lowest level to have the ultimate power over what is referred to as community lands, customary lands and to a certain point, it may cover the entire woeste land (waste lands) existing on the East Coast of North Sumatera, the home of a group of people called the Melayu Pe$\operatorname{sisir}^{2}$ (the Malay people dwelling the coastal

In Deli, North Sumatra for instance, there are 4 (four) main Kedatukan which form the Kesultanan Deli, i.e. Kedatukan Soenggal, Kedatukan XII Koeta, Kedatukan Sukapiring and Kedatukan Senembah. The Sultan of Deli should get an approval from the Datuk in land distribution to other party. Batak War or Soenggal War in 1872 between Kedatukan Soenggal and Dutch Indie Governmnt is a good example to show the right's position of the Kedatukan when they were not involved in making of land concession contract between Kesultanan Deli and a Dutch Plantation Company in Soenggal region.

2 Malay Pesisir is a familiar term in North Sumatra to place all the Malay inhabitants living in the East Coast of North Sumatra, from Langkat Regency in the north to Labuhan Batu in the southward. The Malay Deli is one of the Malay Pesisir and the most widely discussed in Colonial literature especially since the areas). The politicization and seizures of power as shown by Reid ${ }^{3}$ and Stoler ${ }^{4}$ had successfully encouraged the existing Kings to achieve the peaks as the Intermediaries of the people, the highest people's chiefs, as symbols of religious and cultural keepers of the Malay people, most especially during which time they were forced to be in a very low state of living quality.

The king's political space was actually very limited as once shown by Perret. It was apparently understood that the political integrity of a kingdom would be too much depending on the loyalty of the surrounding elites, such as: the datuk (the progenitor) the tengku (the noblemen), the orang besar (the respected individuals), the orang kaya (the haves and the well-done peoples). In the land of Deli, the king must take into account all of the existing posts in his kingdoms' hierarchy such as the Viceroys, the Secretary of the Kingdom and the holder of the court and police affairs, harbormaster: the holder of the port administrative affairs and relationships with foreigner and not less important was to take into account what was so called the $D a$ tuk Empat Suku (XII Kuta, Sunggal, Sukapiring and Senembah). ${ }^{5}$ Unlike in Langkat, the King would stay calmly in his throne wait-

raise of tobacco plantation in this region. Malay Pesisir is undoubtedly Moslim. Ruled by The Sultan Deli and their four Datuks and some other small local chieftains. The Independence of Indonesia in 1945 ended the power of the Sultan and Datuks upon their people. Nowadays, The Sultanate is functioned as the Head of Malay Adat Council.

3 Anthony Reid (1987). Perjuangan Rakyat: Revolusi dan Hancurnya Kerajaan di Sumatera Timur. Jakarta: Sinar Harapan.

4 Ann Laura Stoler. (1985). Capitalism and Confrontation in Sumatra's Plantation Belt, 1870-1979. The University of Michigan Press.

5 Daniel Peret. (2010). Kolonialisme dan Etnisitas: Batak dan Melayu di Sumatera Timur Laut. Jakarta: Kepustakaan Populer Gramedia, p.141. 
ing for his noblemen to come forward. In the land of Deli, the king must negotiate with all leaders holding position under his rein.

The four territorial groups in the Deli Inland for instance, being directly placed under the authority of the Datuk, well known as Suku (Tribe), gained their mandates from the Penghulu or the village chiefs who were highly trusted by the villagers, namely the Urung, the Kuta or Perbapaan. De Batak Oorlog (Batak's War) had become a testament to how strong position of the people and the heads of the village or the Urung over the land which became the front and back pages of their settlement. It was all then so baseless of what was mentioned by Kalo in his work of his study in this area plainly stating that the position of the King in the absolute Sultanate of Deli was just like the shadow of King Louis XIV in France, with his famous saying L'etat c'est moi (I am the state). ${ }^{6}$ The King of Deli was not a monarchy as it is commonly known in the kingdoms of the Europe. Here, the King was just an extension of an llegal engagement that barely utilized the existing political space for the

\footnotetext{
Kalo had mentioned: "In Europe before the France Revolution a doctrine was applied that A King was all the ruler of all things within his kingdom with a slogan "L'etat c'est Moi" or I am the State. This theory had reflected such huge authority over the existing lands. A king had been positioned as the representative of a State and as the owner of lands and the State. Such a theory was also applied in both Britain and the Netherlands. Indonesia as the Dutch colonized country had totally applied this theory, which meant that all lands in Indonesia were belonged to the Kings and therefore as the Kings were subject to the colonial government, it had brought logical consequences that all lands in the colonized country should be converted into the ownership of the King of the Netherlands." In addition, see Syafruddin Kalo (2004), Perbedaan dalam Persepsi Terkait Hak Tanah dan Pengaruhnya Terhadap Komunitas Petani di Sumatera Timur, Medan: Program Studi Hukum Pidana, Faculty of Law, University of Sumatera Utara. p.7.
}

sake of his own and of his people. ${ }^{7}$

Some secondary evidences have apparently shown that the situation in Deli upland inhabited mostly by the people of Karo tribe was somewhat different from some of those lowland areas. The relationship between people and the the land was constructed or formed through a strong kinship system and and greatly appreciating the clans who had initially started and opened the village. The Village Chiefs generally came from the clans of the first settlers who initially opened the village or Kuta, quite different from the Deli lowland, it was clearly seen that even though the Penghulu or village chiefs were regarded as respected persons in terms of land organization, but their position was not even more powerful than their colleagues at the Deli upland. It was clear that the arrangements relating to lands administration in the Deli lowlands was built so openly to ensure enough rooms for many people to manage the abundant lands by means of agriculture widely known as Reba (swidden culture).

The influx of Islam in Sumatra, at a certain period in the seventh until twelfth centuries has strengthened the position of the customary law (over land tenure) of the Malay Deli in this region and to some extent it has entered into a religious arrangement and in later stages it has obscured the natural characteristic of the customary law itself, most especially regarding land tenures of the initial groups having settled themselves in this region. Religion has become an important elan that ensures everyone to get their rights. People who previously had embraced indigenous religions or Hindus has chosen to

\footnotetext{
See further on Stoler, Loc.cit.
} 
convert to Islam in order to get opportunities to cultivate lands existing under the leadership of the Penghulu, Datuk and even under the Sultan.

Terminology of embracing to Malay (Masuk Melayu) had become such a popular trend referring to people who converted their religions to Islam. Peret recorded this in Riwayat Hamparan Perak (the Chronicles of Hamparan Perak) back to the time when Guru Patimpus claimed: "We have our lands extending to the sea. I think, if we hadn't converted to Islam, our land would certainly have been seized by the Jawi of the overseas." ${ }^{\text {Q }}$ Quite explicitly, in a colonial report, the renting and selling of lands to any third party should first be deliberated with the Penghulu Kampung (the headmen) and with the Datuk Urung (clan leaders). It was simply because they were the ones holding the power with authority to make arrangement of all policies within their areas of power, whilst the Sultan Deli was by himself not entitled to any rights to release or give away any concession of land to any foreign businessmen, most especially without participating the Penghulu Kampung and the Datuk-datuk Urung. ${ }^{9}$

Mahadi said: "If woeste grond was translated as forest-land, a land with no particular person admitted it as a right, then we can depart from this standpoint with a proposition that the Sultan/the King was also not the owner of the land (even in the original arrangement it was even said: Sultan/the King never even claimed the lands as theirs. ${ }^{10}$ Even

8 Perret, Op.cit. p. 148; Simanjuntak B.S (1977). Sejarah Batak. Balige: Karl Sianipar Company.

Mail Report No.213, 31 December 1872.

10 Mahadi (1976). Sedikit Sejarah Perkembangan HakHak Suku Melayu atas Tanah di Sumatera Timur (1800- though at first stage Mahadi was little doubtful in showing the most appropriate parties to be regarded as the owner on the Woeste Grond, but from the elaboration of the data, which he described later, he came to the conclusion, by borrowing the words of a Dutch scholar, Lekkerkerker, de Regeling van de beschikking over gebruiksrechten op grond toekomst aan gemeenschappen (the arrangement and power over lands lies in the hands of the community). ${ }^{11}$ The king's sole rights never existed. Even if the king considered himself (zich beschouwen) as the owner of the land, then we have to examine that assumption with regard to historical contexts on the rise of someone until he came to sit on the throne of the kingdom, that was through war and disputes.

\section{Concession Contract Traps Over Com- munal Lands}

The previous assumptions that said the king had power over the lands had formed the standpoint of the earlier planters who would want to gain facilities in exploiting the available lands. This was not of a right or wrong condition. The planters really knew to whom they had to come around and tried to get permission to commercialize the existing land there. During the fourteen years' period, ever since the first Nienhuijs once received a tobacco plantation concession, King or Sultan Deli and other Sultans had lustfully enjoyed the freedom in formulating a longterm land lease. For a king, before the application of the standardized concession

1975). Bandung: Penerbit Alumni.

11 J.G.W. Lekkerkerker (1928). Concessie en Erfpachten ten behoeve van Landbouwondernemingen in de Buitengewesten van Nederlands Indie. Groningen-Den Haag, JB.Wolters. p.112. 
contracts of 1877 widely used, the contents of such contracts would not be so important. All land taxes collected to fill up their pockets had seemed to be much more important.

The concession contract was apparently a concept that was heavily influenced by the ideas of the Netherlands that had become early experiments for the entry of foreign elements in the normative setting here. Labberton $^{12}$ had indicated how such a capitalistic model being widely used the terms of concession. Some of the terms were: a. a contract is only carried out upon the approval of local governments; b. a contract is managed independently; c. a contract is not transferred without prior consent of the government; d. No population is allowed to reside within concession areas; e. any workers employed within are obtained voluntarily.

Other colonial perspective which also had implications on the issues of land tenure and its relationships with the people was the interpretation of woeste grond or wasteland. The interpretation used by the Dutch government on woeste ground and had clearly shown the perspective of the "West" on lands, with Woeste Grond to be defined as a land that was not cultivated or occupied by the indigenous population and also was not of common property and or not included within the power of leadership/headmen (gronden, niet door de inlanders ontgonnen, noch als gemeene weide of uit eenigen anderen hoofde tot de Dorpen behoorende). ${ }^{13}$

Is there any land, which is not cultivated in the perspective of the indigenous people, and therefore there is no one entitled

\footnotetext{
12 K. van Hinloopen Labberton (1903). De Indische Landbouw Consessie. Amsterdam: JH. De Bussy.

13 Lekkerkerker. Op.cit. p. 71.
}

to it? Pelzer had pointed out that in the eyes of the Malay and Batak people, there is no land completely unused, because all the land is regarded useful as a hunting ground and is also used to produce forest products such as: building materials, fire wood, resin, food, raw materials for the making of tools, and many other products. And on top of that, any existing land is a potential for farming. In short, all lands in any way supports the entire life of its inhabitants. ${ }^{14}$

Concession Deed, which according to some scholars, such as Mahadi, Perret and Pelzer just to mention a few of them, as the best source to see the recognition of the colonial and the Dutch businessmen in relation to communal land rights of the Malay and the Malay population in other Sultanates as cannot be blamed. However, none of the experts mentioned above looked more deeply as Buffart did who had seriously alleged that the deed of concession was sort of a normative accident that had caused people or indigenous groups to be so deprived of their land as regard to the substance or content of the concession. I should further declare that the concession is also a trap that has deprived the position of the people who live in villages in the pursuit of managing their lands.

The evidence that it is only a trap and accessories (accesoir) of interests between the planters, the Sultan and the Dutch East Indies clearly can be seen from the way they are adjusting the definition on who is defined as population (bevolking or opgezetenen) and also the duration of the giving of the Jaluran

\footnotetext{
14 K. Pelzer (1978). Planters and Peasant: Colonial Policy and The Agrarian Struggle in East Sumatra 18631947. Verhandelingen KITLV No.84, 'S-Gravenhage: Martinus Nijhoff. p. 96.
} 
(land for tobacco that has been completely harvested). ${ }^{15}$ Another fact can be seen from the land concession permits, which was before the introduction of concession, could be carried out without having to have approval. On the contrary, by now, the populations should have obtained permits from the concession holders if they want to manage or cultivate a piece of land within borders of the concession.

Customary land law that had previously existed and applied in social behavior are forced to succumb to the issuance of the concession contracts. I should assert that the new relationships between the population who live adjacent to the concession land, in the post of concession contract application between the Sultanate of Deli and the foreign Businessmen, is of a consequence of the enactment of the said contracts. The Jaluran lands that is regarded as a sort of customary land in the life of Malay people herein, by Mahadi may also be positioned as a new legal relation resulting from merger of various capitalist's interests of the plantations in the one hand, and as of the Sultan's opportunity to manifest himself as the intermediary of the people in his kingdom.

As both a new legal relation and the compensation over the characteristics of tobacco plants that need times to remain fallow so some lengths of period until comes the next planting period, then the Jaluran lands is the only lands that is regarded by many as a marker of communal land among the Malay people and the surroundings. In the context of the last thing mentioned herein, we need to be more aware to come to a certain

15 See also Stoler. Loc.cit conclusion; whether or not the Jaluran land, as the marker of a sort of communal land as already pointed out by Mahadi would be just different from the statement saying that the Jaluran land is a sort of the Communal Land belonging to the Deli Malay, as has always been echoed by a group of customary land strugglers.

I would be more in the agreement that the Jaluran land is only serving as a marker, because long before the foreign planters came to seize the land in this areas, there had been social institutions regulating how someone had to manage his land, whatever trees were allowed to be felled, and whatever markers that should be made by someone in the even he wanted to cultivate and manage his land, whatever obligations that should be conducted as a result of managing and cultivating his land, and so on. Another reason is that because the terminology for the Jaluran land was not even found before, nor within it was found within the records made by Anderson in the beginning of $19^{\text {th }}$ century and others. It was only found within the Dutch literatures by the end of the $20^{\text {th }}$ century. A sort of land/forest said as "reba", may be more appropriately mentioned as a kind of communal land in this region long before the foreign planters and the Dutch colonial entered this region. $\mathrm{Nuh}^{16}$ and Husni ${ }^{17}$ are among few authors who have used this terminology.

\footnotetext{
16 Afnawi Nuh (1998). "Dari Petani Reba ke Petani Jaluran", on "Pembangunan Berbuah Sengketa; Kumpulan Kasus-Kasus Sengketa Pertanahan Sepanjang Orde Baru". Medan: Yayasan Sintesa dan Serikat Petani Sumatera Utara (SPSU), p. 135.

17 Tengku Lah Husny (1975), Lintasan Sejarah Peradaban dan Budaya Penduduk Melayu Pesisisir Deli di Sumater Timur 1612-1950. Medan: Badan Penerbit Husny, p. 100.
} 
The law of customary law among the Malay Deli people, which has political character and not of being inspired by the symbols of fraternity, such as those applied in Batak land has become something simply easier to be "traded off" at the expense of the elite's interests during that period. The justification regarding the Big Shots of the Sultanate, the Datuk and other high-ranking officials of the kingdom would serve just enough for the Sultan to negotiate with the tobacco planters. All the Datuk, most especially those of the four mentioned earlier (XII Kuta, Sunggal Serbanyaman, Sukap Piring and Senembah) were holding both their strong charisma and positions within their respective authority. And the Sultan needed his people's support through all the Penghulu and the Datuk in order to remain able to accomplish obligations he was entitled to. The fact that the Sultan was not always looking downward and listening directly to the aspirations of the people with regard to the narrowing width of the people's agricultural lands. The War of Sunggal in 1872 can be used as the best example where quite often the aspiration of the people as well as the Kampung (kuta/urung) was obviously neglected.

Since the arrival of Dutch, independence of the village had increasingly been downsized along with the how easy the Sultanate handed the lands within his authority over to the interest of the plantation. The trend of legal pluralism during the first period of (at least before 1877) plantation was indeed already beginning to be seen, however the characteristics of conflicts between the customary law on lands and the Western law, which was stipulated within Concession Deed was not yet showing its original form. Later on, after the concession was standardized, it was only then really felt by the people such as how their previous rights over their lands was suspended, limited and negated by the concession.

\section{Concession Deed as Persoonlijkrecht}

The displeasures of the earlier planters over the contractual characteristic had already been so obvious ever since the very beginning of the standardized concession was applied in Deli, Serdang and Langkat. The capitalists had tried to convince the Dutch government with some supports given by academicians from Law Faculty of Utrecth Universitet, led by Nols Trenite, in order to reform the characteristic of the contracts they had personalized that was what they mentioned as the Dutch Legal System with persoonlijkrecht (personal rights). The concession with its characteristic of persoonlijk according to the plantation businessmen would curtail them to enlarge wider capital expansion from what they had gained before.

The mention of persoonlijkrecht had shown an unequal quality between people who had leased out and the tenants. The sultanate's position that had represented his people had been in the position of the leaser who was so independent to conduct any legal acts against anyone over the land under his rein. Whilst, Nienhuijs and his friends had acted as the tenants who was so free to engage in any civil acts and therefore were obliged and bound to all contents of the contract being mutually countersigned. 
An explicit explanation in a reference document towards investigation of Deli archives in the National Archives of the Netherlands can show various perspectives that are again reflected to public discourse very recently on the status of concessions that had ever been made, either of persoonlijk or zakelijkrecht. The documents reveal: "De overeenkomst werd gesloten op basis van een persoonlijke verbintenis tussen de zelfbestuurder van het betreffendelandschap en de planter. De bestuurlijke invloed van het gouvernement beperkte zich tot de goedkeuring van het concessiekontrakt door de resident." 18

Various efforts by the Dutch businessmen to convert the personal rights to physical rights never had come to reach its climax, even though finally in 1919 an ordinance on the erfpacht for outside of Java and Madura was issued formally. The document answered by itself the failures of the conversion by the following words:

"De invoering van de erfpachtordonnantie stuitte bij de zelfbestuurders van de landschappen Deli, Langkat en Serdang op grote bezwaren. De zelfbestuurders van genoemde landschappen ontleenden hun positie aan een omvangrijk politiek kontrakt, waardoor een eenzijdige invoering van de erfpachtordonnantie van de zijde van het gouvernement werd aangemerkt als aantasting van de bestuurlijke bevoegdheden van de zelf-bestuurders."

\footnotetext{
18 "Agreement was made upon the basis of engagement of personal rights between the ruler of region (the King) and the planter. The influence of the government (the Dutch, author) was only limited to the approval of contract agreement by Resident." Inventaris van het archief van de NV Deli Maatschappij, Dochtermaatschappijen en Gefuseerde Bedrijven, (ca. 1700) 1869-1967 (1968). Nummer archiefinventaris: 2.20.46. P.15.
}

Again and again, the planters failed even though they had gained supports from the government of the Dutch West Indies and its Queen in Den Haag. The Sultanate objections and felt aantasting by the transfer of authority on matters regarding the vast and fertile lands to the hands of the Dutch Government. All efforts had been done, (at least it had been initiated ever since the issuance of the staatsblad 1874 No.79f which regulated the rights of the indigenous people in the opening of farming lands, which was not included as communal ownership or the one that was under the reign of customary leaders, and the Staatsblad 1874 No. 94f upon the titles "Uncultivated Lands in Sumatera", Regulations on releasing the uncultivated lands within the Government of North Sumatera and latter the Stb. Ind. 1875-199a which stated that the agrarian law was fully applicable for colonial lands outside of Java island and Madura. However, the power of the Sultanate as a customary law engagement could not be tamed by the Government of the Dutch East Indies by means only of a political and juridical reason - that the Sultanates were still bound by the political contracts with the Government of the Dutch East Indies.

Van de Waal in his dissertation strengthened an explanation that the concession contracts ever made earlier were of personal rights in nature and was not of physical rights ones. He further mentioned that de landbouw concessie is een persoonlijk recht, berustend op een overeenkomst tussen de Sultan en de concessionaris (the plantation concession was of personal rights in nature and was made based on agreement between the Sul- 
tan and the holders of the concessions). Still in the dissertation it was shown the facts in the Sultanate of Deli, Serdang and Langkat, which covered 5493 plantations, ${ }^{19}$ was neither an erfpacht in nature (which after 1960 through the Agrarian Law No.5/1960 to be converted to Hak Guna Usaha (HGU)/erfpacht), but what was since the very beginning in many written documents as a concession contract.

The Sultanate along with all elites and the people was a legal engagement and was not of a state as imagined by experts of stage governance. The concession was not an erfacht, which after the enactment of Agrarian Law of 1960 became the HGU. Even at the level of jurisdiction various pleading conducted by the companies Vereningde Deli Mij and Senembah Mij in cases of Bremen before the Germany court by reasoning that the concession was of a physical rights in nature, was totally ruled out by the judges and they had agreed with the pleading submitted by Indonesian advocates, in that phenomenal cases, that it was a personal rights in nature and was on the basis of recognition of customary law engagement upon which it was solely based. ${ }^{20}$

19 Notes made by van de Waal revealed that erfpacht was only successfully carried out within the regions being subjected by korte verklaring, such as Simalungun, Asahan and Labuhan Batu. See Robert van de Waal (1950). Richtlijnen voor Een Ontwikkelingsplan voor de Oostkust van Sumatra (proeftschrift), Wageningen: Landbouw Universiteit van Wageningen.

20 Latter, such a case had shown the ambivalence of the Government of Indonesia over the rights of Ulayat over lands originally belonging to the group of Malay Deli people and the surrounding. Before the Bremen Court, Germany, they said that concession lands were all the communal/customary lands of belonging to the Malay Deli people, whilst in the home country they said the lands were all belonging to the State and took the land to be used as State-owned Plantation.

\section{Common Mistakes on Nationalization} and the Fuzziness on the Elimination of

\section{Autonomous Areas}

The prolonged economic crisis in the failures to win diplomatic struggles for Western Irian had become a strong ground when Soekarno declared the nationalizations of the Dutch companies in Indonesia by the end of 1957. The government had seemed to blind itself when such a nationalization was carried out without fairly looking into legal contexts between the Dutch companies and the existence of Sultans in Eastern Sumatera.

Didn't the leaders in Jakarta and all legal experts understand that all lands turned into big plantations in Eastern Sumatera, most especially in Deli, Serdang and Langkat, were all communal lands that had been commissioned to the Sultans in order for them to engage in contracts with the Dutch plantation companies? Did they understand such contracts were actually sorts of a longterm lease and were of personal rights, in nature? It was all so obvious the crucial thing like this was falling out of their mind. With this in mind, it was most likely due to the perspectives related to the state-administration that had seen the Proclamation of 1945 and the enactment of Law No. 1 on The Principles of Regional Governments as strong legal basis for the elimination of the Sultanates, autonomous areas, vorstenlanden and others of the similar kinds.

Factually, at normative level, such an opinion was less reasonable. The elucidations of Law No. 1 of 1957 have stipulated the followings:

"With regard to the existence or the absence of the units of the customary 
law people as the working basis to formulate such an economic level, we shall be aware that autonomous matter is not "congruent" to customary law matters, so that if a unit of customary law people is made into an autonomous area or is included into an autonomous area, then it shall mean that the task of the customary leaders is by itself eliminated. What most likely eliminated is only any matter related to the customary law, which has relation with the state-administration, in nature, in the event that only one unit of customary law be made into an autonomous region, and is merely meant in a nature that is congruent with the power of state-administration that of which is embodied within the meaning of such the autonomy. The capability to look into the differences between the autonomy and power of customary power is of an important requirement to support the life of the autonomy in a satisfactory way for all people who are still trapped within the customary law system, whatsoever." 21

Are civil matters in context of the contract making of plantation concession between two parties, which is binding to each

21 See, the Elucidation of Law No.1 Year 1957, p. 26 Compare to Article 88 verse 3 of the Law No. 18 Year 1965, the Law on the Principles of Regional Government: The Autonomous Region, which is both de facto and dejure, until the time this law is legally enacted, still in existence and its territory has become the territory or part of administrative are of a region, is by fact eliminated. Any arising consequences shall be government by the Regulation of the Ministry of Home Affairs or any authority appointed to it and if deemed necessary whatsoever it shall be settled through Government Regulation. Latter, within article 4 verse 1 on this Government Regulation No. 224 Year 1961, on the Implementation of Land Sharing and the Providence of Compensation, it is said that both Autonomous land and the ex-autonomous land, which is by the dictum IV, point A of Agrarian Law shall be duly transferred to the State, be given allotment, some for the interest of the State, some for the interest of those directly impacted due to the elimination of the autonomous rights and some is given to the people who are in need pursuant to the stipulations of this regulation. party and with an agreement on an object to be included exactly like what has been stipulated within the above law into the principles of customary law of state-administration, in nature? If it is true, then it might be just reasonable for the state, in such a case through the state-administration of Soekarno, to perceive that all lands having been let for the concession to the Dutch to have been regarded as to become the state's lands. Whereas, everyone might know that the leasing aspect on lands is something personal, in nature, and therefore it falls within private domain. Even the state knows exactly that during such a concession was being enacted, there was no such thing known as verponding (Taxes of Land and Building $)^{22}$ imposed over such plantation concession lands. So, it should be questioned how would it be possible then the state to have claimed and decided the civil assets of a group of customary people of Deli Sultanate to become the state's asset.

What has been more naïve, in context of the two lawsuits made by two Dutch companies, in Bremen Court, in Germany, as elucidated previously, the Government of Indonesia, through its advocates and legal experts, to have used its contradictory arguments against what it had performed before its people - the indigenous people of the Sultanate. To the Sultanate and the people, the state claimed that the concession was of a public relation, that was zakelijk recht in nature, and was of a legal act of state administration, in nature, whilst before the Bremen Court, the Indonesia Government stated that

\footnotetext{
22 Both the presence and the absence of tax on Land and Buildings are of the clear distinguishing facts between the concession and the erfpacht. In concession, there is no tax on land and buildings or verponding imposed.
} 
the lands being disputed by the two Dutch companies were of the customary lands and the legal relation between the companies and the Sultanate was of personal rights in nature, or of persoonlijk in nature.

Now the problems become so obvious how the state through Soekarno's administration had used customary shield as a way to win and defend the policy of nationalization. In the mean time, in the home country, communalism in the form of customary land annexation/occupation, was totally rejected or legally denied without giving justice options to the previous owners. At other level, the jargon on nationalization for the available lands previously owned by the customary Deli people during the previous era was quite contradictory to the real meaning of the said nationalization's spirit itself. How would it be possible the jargon of nationalization to be translated as the lands that ever since had been owned by the indigenous people, which had become the supporting parts for the existing government? Or else, the state might had assumed that both the Sultanate and the people were also foreigners and therefore be fully regarded just proper to be falling within the nationalization of their assets.

The Law No. 86/1958 on the Nationalization of the Dutch companies in Indonesia was clearly a total common mistake and had devastated all legal structures existed during that time between the Dutch companies and the groups of people. If such an act had been done upon the Dutch's plantations in Java, the problem would have been different and more reasonable. For all, the Dutch's plantation there had been made falling within the erfpacht with physical rights, in its nature.
However, for the ones in Deli, Langkat and Serdang, the case was totally different. None of them had been falling within ada erfpacht, in the three regions as mentioned beforehand..$^{23}$

The actual denial of the rights to communal land, owned by the Malays in the East coast of Sumatra, had started. The sultanates as previously mentioned did not give any responses at all against the political actions imposed upon them by the state. Such a condition was caused more by the traumatic situations ever since the beginning of the independence id Indonesia, namely the social revolution. The labeling of feudalism and the becoming part of the important Dutch collaborators had impeded the Sultanates to defend plantation lands of the ex-concessions.

Long before the nationalization being enacted, the Sultanate was actually to have been disregarded as the only institution to be taken into account in context of plantation contracts. The intervention in the form of military involvement in matters related to plantation in the post the Japanese exit was indirectly depriving the roles and functions of the Sultanates to be out and further away from the contracts they had ever countersigned before. The framing communities that had become an important basis within law engagement herein did not have any more protection and defense from the Sultanates. Furthermore, many of those who

\footnotetext{
23 With exception of lands in Medan City, which is known as Grant C. A land measuring $\pm 225 \mathrm{Ha}$, in the year of 1891, was excluded from the contract of Mabar-Deli. Within the agreement, Deli Mij was allowed to allot the lands into smaller parcels to the third parties. The rights of acquisition over the land parcels for settlement was also called erfpacht. See further Mahadi. Op.Cit. p.254.
} 
were accused of illegal occupation and thus they have been criminalized by law enforcement authorities.

Suddenly, the rules that were born by a very young country had been very unfriendly to the groups of people, who had been factually and already living more than a generation to manage and cultivate their lands, either through the mechanism of Jaluran and other cultivation licenses, based local culture. Social chaos after the Japanese's defeat of the allies forces to have implicated for the legal mess in the affairs of the lands of former tobacco plantation concession. The legal order was very chaotic and the remaining Dutch plantation was striving for existence by counting on the prevailing institution and the law of state. This chaotic situation had triggered a military intervention into bad habits-habits in the long term in the world within the dark realm of plantation history in East Sumatra or parts of present North Sumatra The plantation in the name of state enterprise and was truly established for the best interest of the state would be just easy to request military backup to banish people's groups trying to retain the lands of the exconcession.

\section{Criminalization of Farmers, New Legal Order and the State's Interests}

New legal order was enacted to banish various argumentations of the people/the farmers who tried to retain of claims over their lands on which they had practiced cultivation for many years. The customs and traditions were defeated by the power. The perspective of legal pluralism, we recollect what has been mentioned by Griffiths: "Whatever the focus, legal pluralism raises important question about power, where it is located, how it is constituted, what form it takes. And all the problem with the weak or classic form of legal pluralism come back to the question of power, that is, power to define law, to apply it and to use it." 24 The local farmers' groups were weakened not only the part of political backup from the Sultanate and other power groups but also, they were weakened in terms of consolidation among the farmers themselves.

The era of fifties has witnessed the supremacy of political parties along with various affiliations, and also reaching the existing farmers groups or those being made existed. The commencement of Badan Perjuangan Rakyat Penunggu (BPRPI) in 1953 as one of centers of traditional farmers struggle was one way taken to "purify" and clarify a group of people who tried to obtain customary lands of the Malay people, and was meant to build consolidation among the Rakyat Penunggu (to mention the indigenous people) by separating themselves to be different from the common format of other land-grabbing conducted by other people's groups. They needed such a power said by Griffiths by rebuilding their collective memories in context of Tanah Jaluran usage and various other aspects taking place in some period before.

Criminalization of farmers taking place in the beginning of the fifties had become an option that had to be accepted by farmers and that was the initial experience they got to know and faced directly with justice in-

24 Jhon Griffith (1986). "What is Legal Pluralism". Journal of Legal Pluralism and Unofficial Law, 24. 
stitution for charges of violation of state law against the state-owned enterprises or plantation. Farmers would only bring their collective memories when tried before the state judges - they were facing the new law orders merely enacted for the sake of the narrow interests of the plantation and the state.

Rejection of local laws as quoted by Tamanaha $^{25}$ and Mommsen \& Moor $^{26}$ that occurred in many colonized countries was in fact continued after they were free from their respective colonial regimes. First, the newly-free countries would accommodate local law, mainly related to customary land law to be included within its main principles. The Law of land was always based customary law, as they always said the land had social function and other socialist's jargons. However, gradually, the rejection over the existence of local institutions was imposed by force, for they were regarded against the "much bigger interests".

The criminalization and deterrent aspects might have become the main motive to banish all claims made by farmers over the ex-concession lands. However, such an experiment was in fact failed. Investigation chambers of the police, the prosecutors, the prisons and courts were none that of being frightened in the face of the Rakyat Penung$g u$ - the indigenous people's struggles. Their Collective memory, back in previous period when they or their parents could still plan

25 Brian Z. Tamanaha (2007). Understanding Legal Pluralism: Past to Present, Local to Global. The Julius Stone Institute of Jurisprudence, Faculty of Law, University of Sydney, The Julius Stone Address 207, Thursday, $5^{\text {th }}$ July.

26 Wolfgang Mommsen \& Jaap de Moor (eds.) (1992). Europeanen Expansion and Law: The Encounter of Europeanen and The Indigenous Law in $19^{\text {th }}$ and $20^{\text {th }}$ Century Africa and Asia. paddy or other cash-crops shortly after tobacco was harvested, was all defeating all kinds of fears - in order to fight back their primordial rights over the customary lands they had owned for generations, which had ever been put in concession with the Dutch enterprises.

Formal elimination of Jaluran in 1968 through the Governor's Decree No. 370/III/ GSU and then strengthened by the Joint Decree of the Minister of the Interior and the Minister of Agriculture, dated 25 April 1969, No. 52 of 1969 and 141/Kpts/4/1969 had become an important note in this region as the official state's rules designed to eliminate one of the markers of communal rights that had ever existed among some Malay Deli people who had inhabited the areas around the plantations. The decree of North Sumatera Governor, at that time, Marah Halim, strongly stating that the Jaluran was cultivated with rice by Perusahaan Terbatas Perkebunan (PTP) IX ${ }^{27}$ was a weird fact and misleading at all. It was weird because PTP IX just did not have any experience to plant paddy. It was said as misleading because such lad had been planted by groups of the Indigenous people's struggles. Whilst, crash-crops might be planted so long as the time was remaining available, after paddy harvest.

The Malay people as the indigenous population of this region were treated as if they had been beggars in their own ancestor's land. Being accused as criminals, being tricked by making use of the Criminal Code

\footnotetext{
$27 \quad$ PTP IX is a state company and are merged with PTP II in 1996 based on State Regulation Number 7/1996, and nowadays been known as PT Perkebunan Nusantara (PTPN) 2.
} 
and thus continued until after the reform of the Plantation Act 18 of 2004. The state's law had become knife stabbing into the heart of the life of the Mlay people who are weak in terms of solidarity perspective, social structures and cohesiveness. The state's law was relatively not too difficult to tame the indigenous Malay groups, even worse after the position of the Sultanate reached its weak point over the accusation and stigmas given to them as feudal stigmatization, groups that enriched themselves and collaborators of the Dutch.

The characteristic of weak legal pluralism due to the strong domination of legal state along with its players, such as plantations, thus accelerated stronger perspectives among the state's bureaucrats as well as justice institutions on the already and totally eliminated local authorities that had ever existed before at the point of legal engagement in this region. Historical accounts were not used as important basis in the policy making of the government, and it was even worsened by the fact of low understanding among the people to comprehend all situation created during this period, most especially in terms of plantation concessions being made so far.

The emergence of reform era 1998 and the adoption of the decree of Agrarian Ministry/the Head of National Land Board No. 05/1999 to would seem to give a little hope for better management and harmonization between the state's law and customary law on land matters. However, when criticized a bit further with regard to the technical decree issued by central government, it was all legal camouflage, which again and again, would show its overwhelming power against peo- ple's aspiration with regard to the diminishing original rights of the people. Article 3 of the technical decree stated:

The fulfilment of customary rights as elaborated in article 2 shall not apply for types of land, during which time the Regional Regulation be formally adopted pursuant to Article 6: a. had already been owned by individuals and legal entity with basis of rights over the lands in accordance with the Main Agrarian Regulation; b. types of lands that have been obtained or freed away through government institutions, legal entity or individuals in accordance with the prevailing rules and common practices.

This article has even locked and limited as well as trapped all opportunities primordially possessed by the Malay people in this region in order to heighten the formal recognition of the state against their existence over their communal lands.

In this way, it has been crueler than the traps made by planters within the concession deeds elaborated beforehand. The government along with the rules created on the ground would dictate problems without looking into the origins of the problems themselves - a process on how the cultivation permit or the $H G U$ of the plantations being issued and the release of the ex-concession lands to the third party. The state's law has not become so adaptive of protecting the living basis of the people who were indigenously in possession of the primordial rights to the lands. De-legitimization and the de-sacredness over the customary lands, with such a positivity's orthodox perspec-tive was apparently not anymore congruent to one of the principles of Rule of Law; whereas 
everyone is rightful over recognition, security, protection and legal certainty, that is just and equal treatment before the law.

At this junction, it is evident that money interests and power have become new idols in the decision-making of the lands of ex-plantation concession. Such lands can be transferred to the hands of anyone so long as there is nominal clarity of the transferring modus. A number of land officers, plantation elites, government executives, black advocates, judges of courts and police investigators as well as prosecutors, all have become case-brokers in order to fulfill and satisfy the thirst and the desire of capital owners over the acts of transfer of the ex-concession lands.

\section{CONCLUSION}

One hundred and fifty years ever since Nienhuijs obtained his first land concession for tobacco plantation in this fertile area, the law or whatever it might be termed those that was already created by the existing institutions of power had become the weapon of the strongest in ruling out, controlling, manipulating and taming as well as to banish the local living laws existed long before their period. This Paper would frankly conclude that such a thing is of an unequal normative contestation, which is again and again, obviously showing how ferocious is the power of hegemony and the diminishing of the spirit of justice in protecting groups of the weak peoples. This further reveals that the state's law is coming away from its protective characteristic over all segments of peoples, and at the same time, has become a common enemy that should be fought back no matter what it takes - at the expense of its denials upon the history and origins of the land tenure.

\section{BIBLIOGRAPHY}

Griffith, Jhon. (1986). "What Is Legal Pluralism",, Journal of Legal Pluralism and Unofficial Law, 24.

Husny, Tengku Lah. (1975). Lintasan Sejarah Peradaban dan Budaya Penduduk Melayu Pesisisir Deli di Sumatera Timur 1612-1950. Medan: Badan Penerbit Husny.

Kalo, Syafruddin. (2004). Perbedaan dalam Persepsi Terkait Hak Tanah dan Pengaruhnya Terhadap Komunitas Petani di Sumatera Timur. Medan: Program Studi Hukum Pidana, Faculty of Law, University of Sumatera Utara.

Labberton, K., van Hinloopen. (1903). De Indische Landbouw Consessie. Amsterdam: JH. De Bussy.

Lekkerkerker, J.G.W. (1928). Concessie en Erfpachten ten behoeve van Landbouwondernemingen in de Buitengewesten van Nederlands Indie. Groningen-Den Haag: JB.Wolters.

Mahadi. (1976). Sedikit Sejarah Perkembangan Hak-Hak Suku Melayu atas Tanah di Sumatera Timur (1800-1975). Bandung: Penerbit Alumni.

Mommsen, Wolfgang \& Jaap de Moor (eds.). (1992). Europeanen Expansion and Law: The Encounter of Europeanen and The Indigenous Law in 19th and 20th Century Africa and Asia.

Nuh, Afnawi. (1998). "Dari Petani Reba ke Petani Jaluran", in: Noer Fauzi and Boy Firdo (Eds.), Pembangunan Berbuah Sengketa; Kumpulan Kasus- 
kasus Sengketa Pertanahan Sepanjang Orde Baru. Medan: Yayasan Sintesa dan Serikat Petani Sumatera Utara (SPSU).

Pelzer, K. (1978). Planters and Peasant: Colonial Policy and The Agrarian Struggle in East Sumatra 1863-1947. Verhandelingen KITLV No.84, 'SGravenhage: Martinus Nijhoff.

Perret, Daniel. (2010). Kolonialisme dan Etnisitas: Batak dan Melayu di Sumatera Timur Laut. Jakarta: Kepustakaan Populer Gramedia.

Reid, Anthony. (1987). Perjuangan Rakyat: Revolusi dan Hancurnya Kerajaan di Sumatera Timur. Jakarta: Sinar Harapan.

Simanjuntak B.S. (1977). Sejarah Batak, Balige: Karl Sianipar Company.

Stoler Ann, Laura. (1985). Capitalism and
Confrontation in Sumatra's Plantation Belt, 1870-1979. The University of Michigan Press.

Tamanaha, Brian Z. (2007). Understanding Legal Pluralism: Past to Present, Local to Global. The Julius Stone Institute of Jurisprudence, Faculty of Law, University of Sydney.

Van de Waal, Robert. (1950). Richtlijnen voor Een Ontwikkelingsplan voor de Oostkust van Sumatra (proeftschrift). Wageningen.

\section{Archives}

Inventaris van het archief van de NV Deli Maatschappij, Dochtermaatschappijen en Gefuseerde Bedrijven, (ca. 1700) 1869-1967 (1968). Nummer archiefinventaris: 2.20.46.

Mail Report No.213, 31 December 1872. 